\title{
VASCULAR ENDOTHELIAL GROWTH FACTOR (VEGF) IN ABDOMINAL FLUID IN DOGS WITH ONCOLOGICAL AND NON-ONCOLOGICAL DISEASES
}

\author{
Tsanko Hristov \\ Department of Internal Non-Infectious Diseases, Faculty of Veterinary Medicine, \\ Trakia University, Stara Zagora 6000, Bulgaria
}

Received 15 April 2019; Received in revised form 2 July 2019; Accepted 3 August 2019

\begin{abstract}
The vascular endothelial growth factor (VEGF) is a multifunctional cytokine stimulating the growth of vascular endothelial cells, survival and proliferation, inhibiting apoptosis. It is one of the most potent stimulants of vascular permeability. VEGF is found at high levels in inflammatory and tumour-associated pleural and abdominal effusions and is involved in their occurrence. In the present study, the blood plasma and abdominal fluid VEGF levels were assayed in thirty-one client-owned dogs with neoplastic and non-neoplastic diseases by means of enzyme-linked immunosorbent assay (ELISA). The VEGF concentration in abdominal fluid of dogs $(\mathrm{n}=6)$ with ascites was $190.70 \pm 34.35 \mathrm{pg} / \mathrm{ml}$, in dogs $(\mathrm{n}=6)$ with peritonitis: $1449.81 \pm 365.42 \mathrm{pg} / \mathrm{ml}$ and in $\operatorname{dogs}(\mathrm{n}=9)$ with tumour-associated effusion: $1993.13 \pm 202.56 \mathrm{pg} / \mathrm{ml}$. Blood plasma VEGF of healthy dogs (control group, $\mathrm{n}=10$ ) was $36.79 \pm 5.72 \mathrm{pg} / \mathrm{ml}$, in dogs with ascites: $57.92 \pm 2.88 \mathrm{pg} / \mathrm{ml}$, in $\mathrm{dogs}$ with peritonitis: $76.98 \pm 7.24 \mathrm{pg} / \mathrm{ml}$ and in dogs with tumour-associated effusion: $173.50 \pm 40.9 \mathrm{pg} / \mathrm{ml}$. There were substantial differences between blood plasma and abdominal fluid VEGF levels.
\end{abstract}

Key words: vascular endothelial growth factor, abdominal fluid, tumours, dogs

\section{INTRODUCTION}

The vascular endothelial growth factor (VEGF) is a glycoprotein with strong mitogenic activity on endothelial cells. It mediates the inhibition of some apoptosis mechanisms and thus, enhances cell survival $(1,2)$. It increases vascular permeability (3). VEGF is one of the most potent and earliest inductors of physiological and pathological angiogenesis and lymphangiogenesis (1). Its role in oncogenesis has been confirmed in various types of tumours in humans $(4,5,6)$ and in dogs $(7,8,9)$. In healthy adults, physiological VEGF production is limited to wound healing and the female reproduction cycle $(10,11)$. Researchers have

Corresponding author: Assist. Prof. Tsanko Hristov

E-mail address: hristov_vet@abv.bg

Present address: Department of Internal Non-Infectious Diseases,

Faculty of Veterinary Medicine, Trakia University,

Stara Zagora 6000, Bulgaria

Phone: +359 042699534

Copyright: (C) 2019 Hristov T. This is an open-access article published under the terms of the Creative Commons Attribution License which permits unrestricted use, distribution, and reproduction in any medium, provided the original author and source are credited.

Competing Interests: The authors have declared that no competing interests exist.

Available Online First: 31 August 2019

Published on: 15 October 2019

https://doi.org/10.2478/macvetrev-2019-002 reported high levels of VEGF in inflammatory and tumour-associated peritoneal and pleural fluid in humans $(12,13,14)$. Similar studies in veterinary medicine, in particular in dogs, are limited $(3,15$, 16), which was the incentive for the present study.

\section{MATERIAL AND METHODS}

Thirty-one client-owned dogs, presented to the Small Animal Clinic at the Faculty of Veterinary Medicine, Trakia University - Stara Zagora, were divided in four groups:

- A control group consisting of ten clinically healthy dogs form both genders (5 male and 5 female), of different breeds (German Shepherd, Rottweiler, Staffordshire Bull Terrier, Cocker Spaniel, Pitbull, Siberian Husky, and 4 mix breed dogs), aged 4-11 years. It was used for comparison of plasma VEGF concentration.

- Group I: dogs with ascites ( $\mathrm{n}=6)$, (Table 1)

- Group II: dogs with peritonitis (n=6), (Table 1)

- Group III: dogs with tumour-associated peritoneal effusion $(\mathrm{n}=9)$, comprising of 5 dogs with splenic haemangiosarcoma, 3 with canine lymphoma and 1 with mammary gland carcinoma (Table 2) 
Table 1. Non-neoplastic dogs characteristics

\begin{tabular}{llll}
\hline $\begin{array}{l}\text { Cases of Ascites } \\
\text { Breed }\end{array}$ & Gender & Age (years) & Diagnosis \\
\hline Mix breed & Male & 0.5 & Right-sided heart failure \\
Rottweiler & Female & 9 & Right-sided heart failure \\
German Shepherd & Male & 8.5 & DCMP \\
Mix breed & Male & 10 & Dirofilariosis \\
Rottweiler & Female & 9 & Liver failure \\
French Bulldog & Female & 7 & Liver failure \\
& & & \\
\hline Cases of Peritonitis & & & \\
Breed & Gender & Age (years) & Diagnosis \\
\hline German Shepherd & Male & 3 & Volvulus \\
German Shepherd & Female & 9 & Pyometra \\
Jagdterrier & Female & 8 & Rupture of the uterus \\
Doberman Pinscher & Male & 12 & Prostatic abscess \\
Staffordshire Bull Terrier & Male & 6 & Unknown causes \\
Mix breed & Male & 12 & Perforation of abdominal wall \\
\hline
\end{tabular}

Table 2. Neoplastic dogs characteristics

\begin{tabular}{lllll}
\hline Breed & Gender & Age (years) & Diagnosis & $\begin{array}{l}\text { Clinical stage } \\
\text { (TNM system) }\end{array}$ \\
\hline Mix breed & Male & 16 & Splenic haemangiosarcoma & II \\
Rottweiler & Male & 6 & Splenic haemangiosarcoma & II \\
Bobtail & Female & 12 & Splenic haemangiosarcoma & III \\
Staffordshire Bull Terrier & Female & 14 & Splenic haemangiosarcoma & II \\
Mix breed & Female & 8 & Splenic haemangiosarcoma & II \\
German Shepherd & Female & 13 & Canine lymphoma & IV \\
Rottweiler & Female & 6 & Canine lymphoma & III \\
Rottweiler & Male & 9 & Canine lymphoma & IV \\
Bolognese & Female & 11 & Mammary gland carcinoma & III \\
\hline
\end{tabular}

All dogs with malignancies were with histopathologically confirmed diagnoses.

The blood samples from all dogs were collected by venipuncture of $v$. cephalica antebrachii in standard heparinised containers. Blood plasma for VEGF determinations ( $\mathrm{pg} / \mathrm{ml})$ was obtained by centrifugation $(5000 \mathrm{x} g ; 30 \mathrm{~min})$ of freshly collected heparinised blood.

Abdominal fluid samples were obtained with paracentesis, using a sterile needle (18G) and a syringe $(5 \mathrm{ml})$. The dogs were in lateral recumbency, the fur was removed and the skin was treated twice with disinfectant (5\% iodine tincture). We punctured the ventral abdominal wall, midway between the umbilicus and the xiphoid verruca of the sternum, about 1-2 centimeters from the linnae alba. Immediately after collection, fluid was centrifuged (5000 x g; $20 \mathrm{~min})$. The supernatants were separated and stored at $-20^{\circ} \mathrm{C}$ until analysis. Blood plasma and abdominal fluid VEGF determinations were done with Quantikine Canine VEGF - ELISA (R\&D Systems, Inc. USA, Catalog Number CAVE00) of Tecan Sunrise ELISA reader (Tecan Group Ltd., Männedorf, Switzerland) and Magellan $^{\mathrm{TM}}$ - data analysis software from Tecan.

Statistical analysis of data was performed with Statistica v. 6.1 software (StatSoft Inc., 2002). Data were submitted to ANOVA, followed by StudentNewman-Keuls test. Data are presented as mean and SEM, at a level of significance $\mathrm{p}<0.05$. 
Table 3. VEGF (pg/ml) in blood plasma

\begin{tabular}{lllll}
\hline Traits & $\begin{array}{l}\text { Control group } \\
(\mathbf{C}), \\
(\mathbf{n = 1 0})\end{array}$ & $\begin{array}{l}\text { Croup I (I): } \\
\text { ascites } \\
(\mathbf{n = 6})\end{array}$ & $\begin{array}{l}\text { Groups II (II): } \\
\text { peritonitis } \\
(\mathbf{n = 6})\end{array}$ & $\begin{array}{l}\text { Group III (III): tumour- } \\
\text { associated abdominal fluid } \\
(\mathbf{n}=\mathbf{9})\end{array}$ \\
\hline VEGF $(\mathbf{p g} / \mathbf{m l})$ & $36.79 \pm 5.72$ & $57.92 \pm 2.88$ & $76.98 \pm 7.24$ & $173.50 \pm 40.9$ \\
\hline p values & & C vs I: ns & $\begin{array}{l}\text { C vs II: ns } \\
\text { I vs II: ns }\end{array}$ & $\begin{array}{l}\text { C vs III: }<0.001 \\
\text { I vs III: }<0.01 \\
\text { II vs III: }<0.05\end{array}$ \\
\hline
\end{tabular}

ns: not significant

Table 4. VEGF (pg/ml) in abdominal fluid

\begin{tabular}{|c|c|c|c|}
\hline Traits & $\begin{array}{l}\text { Croup I (I): } \\
\text { ascites } \\
(n=6)\end{array}$ & $\begin{array}{l}\text { Groups II (II): } \\
\text { peritonitis } \\
(\mathbf{n}=6)\end{array}$ & $\begin{array}{l}\text { Group III (III): } \\
\text { tumour-associated abdominal fluid } \\
(\mathrm{n}=9)\end{array}$ \\
\hline VEGF in abdominal fluid (pg/ml) & $190.70 \pm 34.35$ & $1449.81 \pm 365.42$ & $1993.13 \pm 202.56$ \\
\hline p values & & I vs II: $<0.01$ & $\begin{array}{l}\text { I vs III: }<0.001 \\
\text { II vs III: ns }\end{array}$ \\
\hline $\begin{array}{l}\text { VEGF ratio abdominal fluid to } \\
\text { blood plasma }\end{array}$ & $3.29 \pm 0.52$ & $21.47 \pm 6.30$ & $14.48 \pm 2.89$ \\
\hline$p$ values & & I vs II: $<0.05$ & $\begin{array}{l}\text { I vs III: }<0.05 \\
\text { II vs III: ns }\end{array}$ \\
\hline
\end{tabular}

ns: not significant

\section{RESULTS}

The results from the blood plasma VEGF determinations are presented in Table 3 .

Blood plasma VEGF of healthy dogs and dogs with either ascites or peritonitis were not statistically significantly different. Plasma VEGF levels in dogs with malignancies were substantially higher than those of healthy dogs $(\mathrm{p}<0.001)$; also, they exceeded average levels in dogs with ascites $(\mathrm{p}<0.01)$ and peritonitis $(\mathrm{p}<0.05)$.

The results from the abdominal fluid VEGF determinations are presented in Table 4.

As expected, in abdominal effusions VEGF levels in transudate were the lowest $(190.70 \pm 34.35$ $\mathrm{pg} / \mathrm{ml}$ ). Transudate VEGF concentration varied from 127.55 to $229.88 \mathrm{pg} / \mathrm{ml}$ and only in one patient attained $345.07 \mathrm{pg} / \mathrm{ml}$. Average VEGF level in exudate was considerably higher: $1449.81 \pm 365.42$ $\mathrm{pg} / \mathrm{ml}$, with relevant differences vs transudate levels $(p<0.01)$. The lowest measured value in exudate was $294.7 \mathrm{pg} / \mathrm{ml}$, while the maximum: $2500.0 \mathrm{pg} / \mathrm{ml}$. Only in two dogs, exudate VEGF did not exceed $1400 \mathrm{pg} / \mathrm{ml}$. In dogs with tumourassociated peritoneal effusion, VEGF was with highest levels: $1993.13 \pm 202.56 \mathrm{pg} / \mathrm{ml}$, which were substantially different to concentrations in transudate $(\mathrm{p}<0.001)$. Although tumour-associated fluid has significantly higher VEGF levels $(\approx 30 \%)$ than exudate, measured average concentrations were not statistically significantly different. At the same time, in all dogs with malignancy associated abdominal effusion, VEGF levels were over 1100 $\mathrm{pg} / \mathrm{ml}$, and in 5 out of all 9 dogs $(55.55 \%)$ VEGF exceeded $2000 \mathrm{pg} / \mathrm{ml}$.

The ratio of abdominal VEGF to blood plasma VEGF was the highest in dogs with peritonitis (21.47 \pm 6.30 ), followed by ratio in dogs with malignancies (14.48 \pm 2.89$)$. In dogs with ascites, the ratio was considerably lower $(3.29 \pm 0.52)$.

\section{DISCUSSION}

The exact origin of circulating vascular endothelial growth factor is a subject of controversy. It is confirmed without any doubt that many tumour types could produce their own VEGF. Also, blood plasma VEGF are directly related to tumour histology (higher levels in malignant and aggressive tumours) and metastasizing $(17,18)$. Our results agree with these facts. High blood plasma concentration of circulating VEGF are due to enhanced gene expression, production of 
the growth factor by tumour cells and the effect of inflammatory cytokines released consequently to neoplastic growth infiltration (19).

The present study confirmed the presence of VEGF in abdominal fluids of different origin. The average level of VEGF in tumour-associated peritoneal fluid was about tenfold higher than levels in ascitic fluid of non-oncological patients. On the other hand, there was not a significant difference between peritoneal VEGF levels in dogs with malignancies and dogs with peritonitis. This data is comparable to those of certain researchers $(20,21)$, but not to others (16). Corresponding to another similar report (16), we also found out that abdominal fluid VEGF exceeded many times levels in corresponding blood samples. This proves the local accumulation of VEGF in abdominal effusions of various origins. The difference between plasma and peritoneal levels was the lowest in animals with ascites (2 to 5 times), whereas in most dogs with malignancies and inflammatory non-neoplastic diseases the difference is about or over 10 times.

The question regarding the appearance and the role of VEGF in the formation of peritoneal and pleural effusions in patients with and without tumours is disputable. Tissue hypoxia (in inflammations or congestive states) is one of the key factors initiating VEGF synthesis. Increased VEGF production enhances angiogenesis, which resultantly increases tissue perfusion as well as vascular permeability (22). The stimulating effect of various proinflammatory cytokines and growth factors as transforming growth factor alpha (TGF- $\alpha$ ), tumour-necrotizing factor (TNF- $\alpha$ ), interleukin-1 and interleukin-6 (IL-1, IL-6), insulin-like growth factor 1(IGF-I), prostaglandins E1 and E2 (PG-E1, -E2), cyclooxygenase-2 (COX-2) etc., is also relevant for VEGF synthesis in inflammatory states $(23,24)$. Last but not least, the immediately tumourproduced VEGF released in the circulation and sometimes, directly in the abdominal fluid, should be taken into consideration. The complex effect of these mechanisms in diseases accompanied with abdominal effusion, leads to increased local production of VEGF in the abdominal cavity in a variety of disease states. The extent of involvement and the activity of mentioned factors (hypoxia, cytokines, tumour secretion) in our view are at the background of differences in abdominal fluid VEGF concentrations in congestive, inflammatory and malignant diseases. On its part, the produced VEGF has a direct influence on the formation of pleural and peritoneal effusions through enhanced permeability of blood vessels. The effect of VEGF on vascular permeability is about 50,000 times stronger than that of histamine (23).

The concentration of VEGF in peritonitis abdominal fluid was far higher than levels in noninflammatory ascitic fluid $(1449.81 \pm 365.42 \mathrm{pg} / \mathrm{ml}$ vs $190.70 \pm 34.35 \mathrm{pg} / \mathrm{ml})$. This could indicate that the effect of proinflammatory cytokines is multiple times more potent than that of local tissue hypoxia for triggering VEGF synthesis. In malignancyassociated effusion, the combined effect of local tissue hypoxia (due to circulatory troubles), inflammatory cytokines (in tumour infiltration) and tumour-synthesized VEGF is involved.

\section{CONCLUSION}

The levels of vascular endothelial growth factor in blood plasma and peritoneal effusion in oncological canine patients are extremely high compared to those in dogs with ascites. This could be used as an additional diagnostic approach. High VEGF levels $(>2000 \mathrm{pg} / \mathrm{ml})$ in abdominal fluid are more likely to indicate neoplastic origin of the effusion. Additional research is necessary to elucidate the importance and role of VEGF in abdominal fluid of dogs with oncological and nononcological diseases.

\section{CONFLICT OF INTEREST STATEMENT}

The authors declared that they have no potential conf lict of interest with respect to the authorship and/or publication of this article

\section{ACKNOWLEDGEMENTS}

This study is financially supported by Faculty of Veterinary Medicine, Stara Zagora, Bulgaria and Ministry of Education and Science, Republic of Bulgaria. The results presented in this paper are a part of a project.

\section{REFERENCES}

1. Ferrara, N. (2004). Vascular endothelial growth factor: basic science and clinical progress. Endocrine Reviews 25(4): 581-611.

https://doi.org/10.1210/er.2003-0027

PMid:15294883 
2. Pidgeon, G.P., Barr, M.P., Harmey, J.H., Foley, D.A., Bouchier-Hayes, D.J. (2001). Vascular endothelial growth factor (VEGF) upregulates BCL-2 and inhibits apoptosis in human and murine mammary adenocarcinoma cells. Br J Cancer. 85(2): 273-278. https://doi.org/10.1054/bjoc.2001.1876 PMid:11461089 PMCid:PMC2364032

3. Takano, T., Ohyama, T., Kokumoto, A., Satoh, R., Hohdatsu, Ts. (2011). Vascular endothelial growth factor(VEGF), produced by feline infectious peritonitis (FIP) virus-infected monocytes and macrophages, induces vascular permeability and effusion in cats with FIP. Virus Research 158, 161-168. https://doi.org/10.1016/j.virusres.2011.03.027 PMid:21473893

4. Zhao, X., Xian, S., Xiao-li, L. (2012). Expression and clinical significance of STAT3, P-STAT3, and VEGF-C in small cell lung cancer. Asian Pacific J Cancer Prev. 13, 2873-2877. https://doi.org/10.7314/APJCP.2012.13.6.2873 PMid:22938476

5. Ghasemi, M., Omid, E., Farshad, N., Ahmadreza, B., Saeid, A., Laleh, V., Moghimpour, R. (2011). Immunohistochemical expression of vascular endothelial growth factor and its correlation with tumor grade in breast ductal carcinoma. Acta Medica Iranica 49(12): 776-779.

6. Stefanou, D., Anna, B., Sevasti, K., Evdokia, A., Dionysios, J.P., Niki, J.A. (2004). Expression of vascular endothelial growth factor (VEGF) and association with microvessel density in benign prostatic hyperplasia and prostate cancer. In Vivo 18(2): 155-160.

7. Campos, A.G., Campos, J. A., Sanches, D. S., Dagli, M. L., Matera, J. M. (2012). Immunohistochemical evaluation of vascular endothelial growth factor (VEGF) in splenic hemangiomas and hemangiosarcomas in dogs. Open Journal of Veterinary Medicine 2, 191-195.

https://doi.org/10.4236/ojvm.2012.24030

8. Martano, M., Restucci, B., Ceccarelli, D. M., Muzio, L. L., Maiolino, P. (2016). Immunohistochemical expression of vascular endothelial growth factor in canine oral squamous cell carcinomas. Oncology Letters 11, 399-404.

https://doi.org/10.3892/ol.2015.3847

PMid:26870224 PMCid:PMC4727185

9. Millanta, F., Andreani, G., Rocchigiani, G., Lorenzi, D., Poli, A. (2016). Correlation between cyclo-oxygenase-2 and vascular endothelial growth factor expression in canine and feline squamous cell carcinomas. J Comp Pathol. 154(4): 297-303.

https://doi.org/10.1016/j.jcpa.2016.02.005

PMid:27012907
10. Barrientos, S., Olivera, S., Michael, S.G., Harold, B., Marjana, T. (2008). Growth factors and cytokines in wound healing. Wound Rep Reg. 16, 585-601. https://doi.org/10.1111/j.1524-475X.2008.00410.x PMid:19128254

11. Robinson, R.S., Woad, K.J., Hammond, A.J., Laird, M., Hunter, M.G., Mann, G.E. (2009). Angiogenesis and vascular function in the ovary. Reproduction $138,869-881$.

https://doi.org/10.1530/REP-09-0283

PMid:19786399

12. Sack, U., Hoffmann, M., Zhao, X.J., Chan, K.S., Hui, D.S.C., Gosse, H., Engelmann, L., Schauer, J., Emmrich, F., Hoheisel, G. (2005). Vascular endothelial growth factor in pleural effusions of different origin. Eur Respir J. 25, 600-604.

https://doi.org/10.1183/09031936.05.00037004 PMid:15802331

13. Bekes, I., Thomas, W.P.F., Tanja, K., Volker, M., Wolfgang, J., Achim, W., Wulff, C. (2016). Does VEGF facilitate local tumor growth and spread into the abdominal cavity by suppressing endothelial cell adhesion, thus increasing vascular peritoneal permeability followed by ascites production in ovarian cancer? Molecular Cancer 15, 13.

https://doi.org/10.1186/s12943-016-0497-3

PMid:26868378 PMCid:PMC4751711

14. Sun, X., Dong, W., Gao, L., Jiang, X. (2003). Detection of VEGF levels in ascites and peritoneal fluid. Chinese Journal of Cancer Research 15(4): 310-314.

https://doi.org/10.1007/BF02974898

15. Askari, V.R., Vafa, B.R., Parvin, Z., Narges, F., Pouria, R., Amir, H.S., Rakhshandeh, H. (2018). Evaluation of the effects of Iranian propolis on the severity of post operational-induced peritoneal adhesion in rats. Biomedicine \& Pharmacotherapy 99, 346-353.

https://doi.org/10.1016/j.biopha.2018.01.068

PMid:29665643

16. Clifford, C.A., Dez, H., Matthew, W.B., Carolyn, J.H., Kenneth, J.D., Karin, U.S. (2002). Vascular endothelial growth factor concentrations in body cavity effusions in dogs. J Vet Intern Med. 16, 164-168.

https://doi.org/10.1111/j.1939-1676.2002.tb02349.x PMid:11899032

17. Wergin, M.C., Kaser-Hotz, B. (2004). Plasma vascular endothelial growth factor (VEGF) measured in seventy dogs with spontaneously occurring tumours. In Vivo 18(1): 15-19. 
18. Kato, Y., Asano, K., Mogi, T., Kutara, K., Teshima, K., Edamura, K. Tsumagari, S., Hasegawa, A., Tanaka, S. (2007). Clinical significance of circulating vascular endothelial growth factor in dogs with mammary gland tumors. J Vet Med Sci. 69(1): 77-80. https://doi.org/10.1292/jvms.69.77 PMid:17283406

19. Wolfesberger, B., de Arespacohaga, G., Willmann, A., Gerner, M., Miller, W., Schwendenwein, I., et al. (2007). Expression of vascular endothelial growth factor and its receptors in canine lymphoma. Journal of Comparative Pathology 137(1): 30-40. https://doi.org/10.1016/j.jcpa.2007.03.003 PMid:17467003

20. Kraft, A., Weindel, K., Ochs, A., Marth, C., Zmija, J., Schumacher, P., Unger, C., Marme, D., Gastl, G. (1999). Vascular endothelial growth factor in the sera and effusions of patients with malignant and nonmalignant disease. Cancer (Phila). 85, 178-187. https://doi.org/10.1002/(SICI)1097-0142(19990101) 85:1<178::AID-CNCR25>3.0.CO;2-7

21. Rudlowski, C., Pickart, A.K., Fuhljahn, C., Friepoertner, T., Schlehe, B., Biesterfeld, S., Schroeder, W. (2006). Prognostic significance of vascular endothelial growth factor expression in ovarian cancer patients: a long-term follow-up. Int J Gynecol Cancer. 16(1): 183-189. https://doi.org/10.1136/ijgc-00009577-20060200100029

PMid:16515588
22. Roskoski, J.R. (2007). Vascular endothelial growth factor (VEGF) signaling in tumor progression. Critical Reviews in Oncology/Hematology 62, 179-213. https://doi.org/10.1016/j.critrevonc.2007.01.006 PMid:17324579

23. Dvorak, H.F. (2002). Vascular permeability factor/ vascular endothelial growth factor: a critical cytokine in tumor angiogenesis and a potential target for diagnosis and therapy. Journal of Clinical Oncology 20(21): 4368-4380.

https://doi.org/10.1200/JCO.2002.10.088

PMid:12409337

24. Queiroga, F.L., Pires, I., Parente, M., Gregório, H., Lopes, C.S. (2011). COX-2 over-expression correlates with VEGF and tumour angiogenesis in canine mammary cancer. Vet J. 189(1): 77-82. https://doi.org/10.1016/j.tvj1.2010.06.022 PMid:20675158 